\title{
Veal colour and other meat quality characteristics in calves fattened on maize silage and concentrate
}

\author{
Dedicated to Professor Dr. Peter Glodek on the occasion of his $65^{\text {th }}$ birthday
}

\begin{abstract}
Summary
Male Holstein (15) and female crossbred (15) calves, weaned from milk replacer at the end of experimental week 8 , were fattened on a maize silage and concentrate diet (MSC). As a control 14 male Holstein calves were conventionally fattened on milk replacer only. The control calves reached the target slaughter weight of about $135 \mathrm{~kg}$ after 24.5 weeks and the MSC males after 28 weeks. The female MSC calves were slaughtered at the same age producing carcasses of $120 \mathrm{~kg}$ on average. MSC males were inferior to control calves in conformation, and MSC females showed the highest fat cover scores. Four MSC males expressed DFD (ultimate $\mathrm{pH}>5.9$ in M. longissimus dorsi (M.l.d.)) and were excluded from further statistical analyses. The MSC calves had a significantly higher iron and pigment content in M.l.d., resulting in a darker $\left(\mathrm{L}^{*}\right)$ and redder $\left(\mathrm{a}^{*}\right)$ colour $24 \mathrm{~h}$ as well as 14 days after slaughter. Early visual judgement and instrumental measurements in the M. rectus abdominis (M.r.a.) $45 \mathrm{~min}$ and $24 \mathrm{~h}$ post mortem, using a colour scale and a Minolta Chroma-Meter, respectively, already showed significantly darker meat with increased redness for MSC calves. However, linear correlations with M.1.d. colour traits were rather low except for redness in M.r.a. 45 min p.m. and aged M.1.d. Haemoglobin concentration in blood, as assessed by a rapid method $3 \mathrm{~d}$ before slaughter, was overall on a relatively high level and showed no significant treatment effect and only weak or no correlation to colour traits. Apart from colour, meat quality of the MSC calves was either superior (shear force, collagen solubility, intramuscular fat, sensory tenderness, juiciness and acceptance) or equivalent (cooking loss, flavour intensity) to control. Therefore, the use of maize silage and concentrate in veal production seems promising, provided a pink veal colour would be accepted by trade and consumers.
\end{abstract}

Key Words: veal, colour, maize silage, concentrate, meat quality, sensory acceptance

\section{Zusammenfassung}

Titel der Arbeit: Fleischfarbe und weitere Merkmale der Fleischqualität bei Kälbern aus MaisilageKraftfuttermast

Bullenkälber der Rasse Holstein Friesian (15) und weibliche Kreuzungskälber (15) wurden nach der Aufzucht mit Milchaustauscher nach 8 Versuchswochen abgesetzt und nur noch mit einer Maissilage-Kraftfutterration (MSC) gemästet. Als Kontrollgruppe dienten 14 männliche Holstein Friesian-Kälber, die konventionell ausschließlich mit Milchaustauscher gemästet wurden. Die Kontrollkälber erreichten die angestrebten Schlachtgewichte von ca. $135 \mathrm{~kg}$ mit 24,5 Wochen und die männlichen MSC-Kälber mit 28 Wochen. Die weiblichen Kälber wurden mit demselben Alter geschlachtet und erzielten Schlachtkörpergewichte von durchschnittlich $120 \mathrm{~kg}$. Die MSC-Bullenkälber fielen im Mittel in geringere Fleischigkeitsklassen als die Kontrollkälber, und die weiblichen MSC-Kälber zeigten die stärkste Fettabdeckung. Vier der männlichen MSCKälber wiesen DFD-Eigenschaften im M. longissimus dorsi (M.l.d) auf (End-pH > 5.9) und wurden von der weiteren statistischen Analyse ausgeschlossen. Die MSC-Kälber zeigten deutlich höhere Eisen- und Pigmentkonzentrationen im M.1.d. und, sowohl $24 \mathrm{~h}$ nach der Schlachtung als auch nach 14-tägiger Reifung, eine dunklere ( $\left.\mathrm{L}^{*}\right)$ Fleischfarbe mit intensiverem Rotton ( $\left.\mathrm{a}^{*}\right)$. Schon die $45 \mathrm{~min}$ und $24 \mathrm{~h}$ post mortem am M. rectus 
abdominis (M.r.a.) sowohl visuell mit Hilfe einer Farbskala bewertete als auch instrumentell mit einem Minolta Chroma-Meter gemessene Farbe zeigte ein deutlich dunkleres, röteres Fleisch bei den MSC-Kälbern. Die Korrelationen mit den Messungen im M.l.d. waren allerdings, mit Ausnahme des a*-Wertes im M.r.a. 45 min p.m. und dem gereiften M.l.d., relativ gering. Der Hämoglobingehalt des Blutes, gemessen mit einer Schnellmethode drei Tage vor der Schlachtung, lag insgesamt auf einem vergleichsweise hohen Niveau und zeigte keine Abhän-gigkeit von der Fütterung und kaum Beziehungen zu Merkmalen der Fleischfarbe. Neben den Farbmerkmalen erwies sich die Fleischqualität der MSC-Kälber derjenigen der Kontrolle überlegen (Scherkraft, intramuskulärer Fettgehalt, Kollagenlöslichkeit, sensorische Saftigkeit, Zartheit und Akzeptanz) oder gleichwertig (Kochverlust, Aroma). Die Mast von Kälbern mit Maissilage und Kraftfutter erscheint daher als eine mögliche Alternative, vorausgesetzt, daß eine rosarote Fleischfarbe von den Abnehmern akzeptiert wird.

Schlüsselwörter: Kalbfleisch, Farbe, Maissilage, Kraftfutter, Fleischqualität, sensorische Akzeptanz

1. Introduction

Colour is still the most important characteristic of veal, regarding the efforts undertaken to classify carcasses according to meat colour as early as possible (e.g. EIKELENBOOM et al., 1992; ANDERSEN et al., 1993), to record the consumer's perception and acceptance (e.g. BAUSCHMID et al., 1992) and to control iron intake in order to achieve a pale colour - sometimes even using chelating agents in the feed to reduce intestinal absorption (POMMIER et al., 1995). A challenge for modern veal production is therefore to find a balance between (i) the demand of trade and consumers for pale veal, (ii) animal welfare considerations, particularly the use of appropriate fibrous feeds as well as supplementation of iron in an amount to avoid subclinical anaemia, and (iii) economical yield. Considering the usually high carcass weights (in Germany about $125 \mathrm{~kg}$ on average, ranging up to $150 \mathrm{~kg}$; ZMP, 1999) and competing alternate products like young, very intensively fattened cattle with carcasses of $160 \mathrm{~kg}$ to $200 \mathrm{~kg}$ (e.g. GERHARDY, 1995) and weaner calves from suckler cow systems, conditions are becoming more and more difficult. One approach to meet the demands of animal welfare and economy may be the fattening of veal calves on grain based diets (MORAN et al., 1991). However, using feeds other than milk and milk replacer will normally result in a dark veal colour and may cause distinct price reductions or even total rejection of the products. The objective of the present investigation was to determine the extent to which veal colour is affected in calves fed a concentrate and maize silage diet, how accurate the expected colour differences to milk replacer-fed calves could be measured either before slaughter or early post mortem (p.m.), and whether other meat quality characteristics are influenced.

Dairy bull calves and female crossbreds from dairy cows are typically used in specialised veal production. In this experiment, 15 male Holstein and 15 female crossbred (Charolais and Limousin $x$ Holstein) calves were fattened on a maize silage and concentrate diet (MSC) after being weaned from milk replacer 8 weeks after the start of the experiment. As a control, 15 male Holstein calves were conventionally fattened on a pure milk replacer diet. At the start of the experiment, the animals were 
on average 2 weeks old and were randomly selected from a total of 225 calves for later carcass and meat quality measurements. The calves were kept on slatted floor, single for 8 weeks and in groups for the rest of the fattening period. In the experimental groups maize silage was supplied ad libitum from the third fattening week on and, different from the control group, continuous access to fresh water was provided.

Depending on the stage of fattening, different types of milk replacer and of concentrate were fed. Table 1 gives the period of application and the composition for all the types of feed used. The milk replacers for conventional fattening were purchased from Alpuro (D-Nordhorn), the feeds used in the MSC feeding system were produced by Provimi B.V. (NL-Rotterdam). Milk replacers and concentrates were allocated according to the schedules recommended by the respective producers. The iron concentration in the milk replacers ranged between 3 and $62 \mathrm{mg} / \mathrm{kg}$ with those designed for the start of fattening containing the higher amounts (Table 1). The declared nutrient contents of the feeds met the respective recommendations. Accordingly, milk replacers and concentrates were both mainly characterised by initially quite constant and then clearly reduced contents of crude protein.

The average fattening period lasted for 24.5 weeks in control and for 28 weeks in the MSC group in order to achieve a comparable average slaughter weight of about $135 \mathrm{~kg}$ for all male calves. According to common practice, the female calves were slaughtered at the same age and with lower carcass weights to avoid excessive fat deposition.

The average iron intake was calculated from the iron contents analysed and the intakes of the feedstuffs recorded, additionally assuming a consumption of $2200 \mathrm{~L}$ of water containing $0.3 \mathrm{mg}$ iron $/ \mathrm{L}$. Blood haemoglobin contents of the selected calves were determined 3 days before slaughter by punctuation of the ear vein and using a rapid

Table 1

Composition of the feed ingredients as fed, either determined by analyses or declared by the manufacturer (Zusammensetzung der Einzelfuttermittel in Originalsubstanz entsprechend Analysen oder nach Herstellerangaben)

\begin{tabular}{|c|c|c|c|c|c|c|c|c|c|}
\hline \multirow{3}{*}{$\begin{array}{l}\text { Ration } \\
\text { Ingredients } \\
\text { Stage of fattening }\end{array}$} & \multirow{2}{*}{\multicolumn{3}{|c|}{$\begin{array}{l}\text { Milk replacer } \\
\text { Milk replacer }\end{array}$}} & \multicolumn{6}{|c|}{ Maize silage/concentrate } \\
\hline & & & & \multicolumn{2}{|c|}{ Milk replacer } & \multicolumn{3}{|c|}{ Concentrate } & \multirow{2}{*}{$\begin{array}{l}\text { Maize } \\
\text { silage }\end{array}$} \\
\hline & I & II & III & I & II & I & II & III & \\
\hline Start of supply (week) & 1 & \multicolumn{2}{|c|}{$9^{\prime}$} & 1 & 3 & 1 & 9 & 19 & 3 \\
\hline End of supply (week) & 8 & \multicolumn{2}{|c|}{$24 / 25^{2}$} & 2 & 8 & 9 & 19 & $24 / 31^{2}$ & $24 / 31^{2}$ \\
\hline \multicolumn{10}{|l|}{ Analysed } \\
\hline Dry matter (\%) & 96.1 & 96.3 & 97.0 & 98.3 & 96.4 & 87.9 & 89.0 & 88.7 & 34.2 \\
\hline $\mathrm{Fe}(\mathrm{mg} / \mathrm{kg})$ & 33.7 & 6.2 & 6.3 & 61.7 & 2.7 & 594.0 & 279.0 & 250.8 & 94.0 \\
\hline \multicolumn{10}{|l|}{ Declared } \\
\hline Organic matter (\%) & 92.5 & 93.5 & 93.5 & 92.5 & 92.5 & 91.5 & 93.0 & 93.0 & \\
\hline Crude protein (\%) & 24 & 25 & 15 & 23 & 22 & 18.5 & 22 & 19 & \\
\hline Ether extract (\%) & 19 & 21 & 21 & 16 & 19 & 3.5 & 3.0 & 6.0 & \\
\hline Crude fiber (\%) & 0.25 & 0.35 & 0.35 & 0.25 & 0.25 & 6.5 & 4.0 & 5.0 & \\
\hline Energy (ME, MJ/kg) & & & & & & 11.0 & 12.2 & 13.0 & \\
\hline
\end{tabular}

TProportions of types II and III declining from a ratio of 0.70:0.30 to $0.45: 0.55$ by weekly adaptation

${ }^{2}$ Depending on the length of the fattening period 
method and equipment from Bayer Diagnostics GmbH (D-Munich) with the set consisting of micro capillaries $(5 \mu \mathrm{m})$, Instant $\mathrm{M}$ haemoglobin cuvettes and a mini photometer (Compur Minilab 2). With this method haemoglobin is transformed into cyano methaemoglobin which gives extinctions at a wave-length of $546 \mathrm{~nm}$.

The selected calves were slaughtered in groups of about five per treatment at three different slaughter dates. In the control group one of the selected animals perished. The animals were slaughtered after 2 to $4 \mathrm{~h}$ of resting subsequent to transport to the slaughter plant. Carcass grading was carried out according to the EUROP classification grid (Anonymus, 1991). Carcasses were weighed 45 min p.m. and meat colour was judged at the M. rectus abdominis (M.r.a.) using a Dutch standard colour scale (IVODLO, NL-Zeist; EIKELENBOOM et al., 1992). Two persons graded the carcasses independently and the individual readings were averaged. Different from the method described by EIKELENBOOM et al. (1992) only the five classes available on the scale were used and not, as suggested, also the virtual intermediate classes. Additionally the recommended light source (Philips TL57) was not available. At the same time colour was measured using a Minolta Chroma-Meter 200b (Minolta, D-Frankfurt) applying light source D56. From the $\mathrm{L}^{*} \mathrm{a}^{*} \mathrm{~b}^{*}$ measures hue angle $\left(\tan ^{-1}\left[\mathrm{~b}^{*} / \mathrm{a}^{*}\right]\right)$ and chroma $\left(\left[a^{* 2}+b^{* 2}\right]^{0.5}\right)$ were calculated. The same grading and measurements were performed at the M.r.a. $24 \mathrm{~h}$ after slaughter. Stated and measured $\mathrm{L}^{*}$, $\mathrm{a}^{*}$ and $\mathrm{b}^{*}$ of the IVO-DLO plates differed to some extent (Table 2).

Table 2

Stated and measured Minolta $L^{*} a^{*} b^{*}$ values of the five class IVO-DLO colour standard for classification of veal (Angegebene und gemessene Farbwerte der fünf Klassen auf dem IVO-DLO-Farbstandard für Kalbfleisch)

\begin{tabular}{lccccccr}
\hline & \multicolumn{3}{c}{$\begin{array}{c}\text { Values given by } \\
\text { manufacturer }\end{array}$} & & & \multicolumn{2}{c}{$\begin{array}{c}\text { Measured with Minolta } \\
\text { Chroma-Meter CR-300 }\end{array}$} \\
\cline { 2 - 4 } Class $^{2}$ & $\mathrm{~L}^{*}$ & $\mathrm{a}^{*}$ & $\mathrm{~b}^{*}$ & 14.3 & $\mathrm{~L}^{*}$ & $\mathrm{a}^{*}$ & $\mathrm{~b}^{*}$ \\
\hline 1 & 60.7 & 6.9 & 13.3 & 61.3 & 13.3 & 11.2 \\
2 & 54.8 & 9.2 & 11.8 & 56.0 & 15.6 & 10.1 \\
3 & 48.7 & 9.5 & 10.2 & 50.3 & 16.9 & 8.5 \\
4 & 42.2 & 11.6 & 9.4 & 45.1 & 17.7 & 7.3 \\
5 & 36.6 & 11.4 & 39.8 & 18.1 & 6.1 \\
\hline
\end{tabular}

${ }^{2}$ Research Institute for Animal Production "Schoonord" (IVO-DLO), Netherlands

Measurement of $\mathrm{pH}$ was done in samples of M.l.d. obtained from the $5^{\text {th }}$ to the $8^{\text {th }}$ rib 26 h p.m. (Portamess 651, Knick, D-Berlin, equipped with an Ingold Xerolyte probe LOT 406-M6-DXK) and colour readings $\left(\mathrm{L}^{*} \mathrm{a}^{*} \mathrm{~b}^{*}\right)$ were taken from a fresh cut of M.1.d. after blooming for $1 \mathrm{~h}$. The samples then were sealed under vacuum. One part was frozen at $-30^{\circ} \mathrm{C}$ until analysed for chemical composition. Another part was stored for $13 \mathrm{~d}$ at $+2{ }^{\circ} \mathrm{C}$ for further $\mathrm{pH}$ and colour measurement, determination of cooking loss and shear force, and sensory analyses. M.l.d. of four male MSC calves showed a $\mathrm{pH}>5.9$ at day 14 , which was defined here as dark, firm, and dry meat (DFD). This sharp limit was set in order to be sure to avoid a confounding between effects of feeding and influences of transport and slaughter technology on $\mathrm{pH}$, which may itself affect colour characteristics of meat directly and to a large extent. 
Iron contents of feeds and M.l.d. were analysed using atomic absorption spectrometry (SpectrAA 300, Varian, Mulgrave Victoria, Australia) after combustion in platinum crucibles at $475{ }^{\circ} \mathrm{C}$ in a muffle furnace. To validate the analysis and to verify the unexpectedly high values, iron contents of the concentrates were also independently determined by an official German feed analysing laboratory (LUFA, D-Hameln) giving equivalent results. Pigment content was determined according to HORNSEY (1956) by dissolving the pigments in acetone and spectral photometric determination at $640 \mathrm{~nm}$.

M.l.d. samples were analysed for the contents of dry matter and intramuscular fat $(\mathrm{HCl}$ hydrolysis and petrol ether extraction; NAUMANN and BASSLER, 1997). Determination of collagen content and collagen solubility were based on the method described by HILL (1966). Cooking loss and instrumental texture traits were determined in M.l.d. after heating the samples in a double-plate grill to an internal temperature of $72{ }^{\circ} \mathrm{C}$ (Therm 3280-6, Ahlborn, D-Holzkirchen). Samples were weighed before and $3 \mathrm{~h}$ after heating for calculation of cooking loss. Maximum shear force is given as the average value of six $1.27 \mathrm{~cm}$ diameter cores per sample obtained from the grilled M.l.d. and sheared rectangular to muscle fiber direction. For this an universal material testing machine (model 4301, Instron Ltd., Buckinghamshire, U.K.) equipped with a Warner-Bratzler shear device, modified for measuring in compression mode, was used. Extension was defined as the distance the blade travelled from the start point to the point of maximum shear force and may be interpreted as a measure of elasticity, reflecting the influence of the collagen-depending compound of meat texture (SCHEEDER, 1992).

Sensory evaluation was performed as a descriptive pairwise comparison by panellists trained according to DIN 10959 and 10961 (German Industry standards). The samples were cooked in a 'Cyclo-Jet' (TecTronic Industries Co. Ltd, Hong Kong) as described previously (SCHEEDER and LANGHOLZ, 1996), and $0.5 \mathrm{~cm}$ thick slices of M.l.d. from two animals were simultaneously served to panellists at monochromatic light conditions in order to exclude any meat colour effects on sensory ratings. The panellists rated tenderness, juiciness, flavour, off-flavour and acceptance on a structured eight-point scale. Furthermore they stated whether the two samples differed not, slightly, clear or very clear and specified the preferred of the two samples. This evaluation was restricted to samples of ten male calves each of control and of the MSC group (excluding DFD).

Data were statistically analysed with SAS (version 6.04, SAS Institute Inc., Cary, NC, USA) applying the 'glm procedure' with the three treatments (control, MSC males, and MSC females) and slaughter date as fixed effects. For this evaluation all MSC male calves showing DFD were excluded. The Scheffé test was performed for multiple comparison among least square means using the 'standard error of estimate'. The tables give the least square means and standard errors of mean (SEM) for the group sizes of 11 and 15 and, in brackets, the mean values inclusive of the DFD calves. Furthermore, colour data were subjected to correlation and regression analyses. 
3. Results and Discussion

Growing concern about animal welfare, probably also taking into account consumer's confidence and economical benefit of veal production, led to several approaches in calf nutrition to determine minimum iron requirements in milk replacer based feeding systems (reviewed by BOEHNCKE and GROPP, 1979; EGGER, 1991; MOREL, 1996; KNAUS et al., 1997) and to investigate alternative feeding strategies for the production of heavy veal calves. Attempts to use supplementary feeds which better consider the demands of ruminant species than the exclusive use of milk and milk replacer diets are nevertheless limited due to the high sensitivity of veal colour to additional iron; and colour still seems to be the most important - or even the only more or less defined quality criterion of veal. Even the intake of litter straw was reported to decrease veal lightness to a certain degree (KRIPPL and BURGSTALLER, 1970). Only more purified "ligno-cellulosic raw material“, which was not nearer described with respect to structure and iron content, had no measurable effect on veal colour in the study of RENERRE et al. (1989), and purified fibrous carbohydrates like cellulose and pectin may even decrease blood haemoglobin (BERNIER et al., 1984). However, since neither the haematological status nor rumination were supported by these additional feeds there seems to be no genuine advantage over milk replacer based systems with respect to animal welfare.

On the other hand, concentrate based diets were already very early suggested to produce heavy veal calves (GIROUX, 1979, cited by BEAUCHEMIN et al., 1990) and grain-based feeding programs for veal calves were described as promising (BEAUCHEMIN et al., 1990) and as an economical alternative (MORAN et al., 1991) to traditional veal production systems - provided darker veal is accepted. Therefore, except when iron-chelating agents such as Ca-EDTA are used (POMMIER et al., 1995; GARIÉPY et al., 1998), a darker meat colour is to be expected when concentrates and roughage are fed to veal calves. In the present study, the effects of a combined concentrate and maize silage diet was tested, which provided both a ration of relatively high energy concentration and fibrous structural components. To judge this alternate approach, not only meat colour but also carcass characteristics, meat quality traits (apart from colour), and sensory palatability were assessed.

\subsection{Carcass quality}

Grain fed veal calves are reported to show a lower dressing percentage compared with milk replacer fed control (BEAUCHEMIN et al., 1990) and either tend to require a longer time to achieve the same carcass weights (POMMIER et al., 1995) or produce slightly lighter carcasses when slaughtered at the same age (QUILICHINY, 1989). On the other hand, grain fed calves may compensate for the low daily gain in the beginning of the fattening period with growing age (BEAUCHEMIN et al., 1990). In the present study, where not only concentrates but also an appreciable amount of roughage was fed, it took about 3.5 weeks more for the MSC calves to reach the same carcass weights as the control animals. However, considering the less expensive feed 
used, this must not necessarily evolve into a serious economical drawback.

The MSC females yielded, as intended, significantly lower carcass weights but already reached the highest fat class grades whereas conformation scores were similar to control (Table 3). Regarding the different genetic origin of the MSC females and the significantly lowest conformation score of the MSC males, it may be concluded that the MSC treatment led to a somewhat inferior carcass grading. These findings are in line with the results of QUILICHINY (1989) whereas BEAUCHEMIN et al. (1990) found only slight differences between grain fed and milk replacer fed calves, and carcass grades improved with increasing carcass weights. Generally, the effects on carcass quality of dietary iron supplementation alone were found to be low (KNAUS et al., 1997; OLIVER et al., 1997) unless growth yield is impaired by a serious iron deficiency which may occur when milk replacers are not iron supplemented (GYGAX et al., 1990). Therefore, the lower average daily gain and carcass grading found presumably resulted from the use of forage decreasing the dietary nutrient density.

Table 3

Carcass characteristics of calves fattened according to different feeding schedules (Schlachtkörpermerkmale von Kälbern aus verschiedenen Fütterungssystemen)'

\begin{tabular}{|c|c|c|c|c|c|}
\hline Ration & Milk replacer & Mai & ize silage/ & trate & \\
\hline Sex & Male & Male & & Female & SEM \\
\hline Observations & 14 & 11 & $(15)^{2}$ & 15 & $11(15)$ \\
\hline Carcass weight $(\mathrm{kg})$ & $134^{\circ}$ & $132^{4}$ & (133) & $120^{6}$ & $3.18(2.74)$ \\
\hline Conformation score ${ }^{3}$ & $3.4^{\mathrm{b}}$ & $4.1^{\prime}$ & $(4.0)$ & $3.5^{\mathrm{b}}$ & $0.15(0.13)$ \\
\hline Fat class ${ }^{4}$ & $2.0^{\mathrm{sb}}$ & $1.9^{\mathrm{b}}$ & (1.9) & $2.2^{\circ}$ & $0.09(0.08)$ \\
\hline
\end{tabular}

\section{2}

Iron supply, haematological status and pigment concentration

The iron concentrations of $275 \mathrm{mg} / \mathrm{kg}$ dry matter as analysed in maize silage were within the range of standard values reported elsewhere (DLG, 1973: $209 \pm 132 \mathrm{mg} / \mathrm{kg}$; NRC, 1988: $260 \mathrm{mg} / \mathrm{kg}$ ). Iron contents of fresh whole maize are much lower (100 to $117 \mathrm{mg} / \mathrm{kg}$ DM; DLG, 1973) suggesting a considerable iron contamination during harvest. The iron contents of the concentrates were even higher (280 to $675 \mathrm{mg} \mathrm{Fe} / \mathrm{kg}$ dry matter) but in a similar range as reported by BEAUCHEMIN et al. (1990) for a barley-based concentrate and a protein supplement with 241 and $640 \mathrm{mg} \mathrm{Fe} / \mathrm{kg}$, respectively. In contrast they reported that corn grain contained only $37 \mathrm{mg} \mathrm{Fe} / \mathrm{kg}$. Similar to forage iron, part of the iron in the concentrates could have come from feed processing.

In both starter milk replacers the $40 \mathrm{mg} \mathrm{Fe} / \mathrm{kg}$ as demanded by the German feed regulations for fattening calves below $80 \mathrm{~kg}$ of live-weight (WEINREICH et al., 1992) were exceeded. Consequently, the less strict current EU regulations (MOREL, 1996) were also fulfilled, requiring a minimum of $30 \mathrm{mg} \mathrm{Fe} / \mathrm{kg}$ at $88 \%$ dry matter until calves are weighing at least $70 \mathrm{~kg}$. The milk replacers supplied at later stages of fattening were considerably lower in iron content amounting to about 3 to $6 \mathrm{mg} / \mathrm{kg}$ 
since no minimum iron contents were specified in the feed regulations for this type of feed. In contrast, Swiss milk replacers have to contain constantly at least $20 \mathrm{mg} \mathrm{Fe} / \mathrm{kg}$ (BUNDESKANZLEI, 1995). The EU and the Swiss strategy are both considered to be without serious consequences on veal colour (EGGER, 1991; MOREL, 1996), but they are still not fully covering iron requirements as was concluded from data on metabolic response of calves subjected to treadmill exercise (LINDT and BLUM, 1994).

In the present study, within the whole fattening period the total iron intake added up to $191.6 \mathrm{~g}$ per head for the MSC calves (milk replacer, $0.4 \mathrm{~g}$, concentrate, $140.1 \mathrm{~g}$, maize silage, $50.4 \mathrm{~g}$, water, $0.7 \mathrm{~g})$ and only to $4.1 \mathrm{~g}$ iron in control $(3.4 \mathrm{~g}$ from milk replacer and $0.7 \mathrm{~g}$ from water). The actual iron intake might have been somewhat higher in both groups due to licking at housing equipment. In turn, the relative group differences in metabolically available iron might have been smaller than the differences in intake since iron supplemented to the milk replacers presumably was of a higher bioavailability than the iron supplied with maize silage and concentrate.

Despite the great difference in iron intake, haematological status was not significantly different when assessed as blood haemoglobin concentration by a rapid method (Table 4). The milk replacer group had numerically lower values but on average remained far from the threshold of clinical anaemia $(<8 \mathrm{mg} / 100 \mathrm{ml}$; LINDT and BLUM, 1994). This was quite unexpected since the milk replacer based ration only had an estimated average iron content of $13 \mathrm{ppm}$. In other investigations, the haemoglobin values found in calves were on average below $10 \mathrm{~g} / 100 \mathrm{ml}$ even when milk replacers with slightly higher iron contents were used (e.g. BERNIER et al., 1984; GYGAX et al., 1990; POMMIER et al., 1995). When iron is provided in excess, there is no further increase in haemoglobin above a certain level (WELCHMAN et al., 1988; KREUZER and KIRCHGESSNER, 1991) thus leading to values of about $13 \mathrm{~g} / 100 \mathrm{ml}$ in both MSC groups.

Table 4

Haematological status as well as iron and pigment concentration in M. longissimus dorsi of calves fattened according to different feeding schedules (Hämatologischer Status sowie Eisen- und Pigmentgehalt des $M$. longissimus dorsi von Kälbern aus verschiedenen Fütterungssystemen) ${ }^{\prime}$

\begin{tabular}{|c|c|c|c|c|c|}
\hline \multirow{3}{*}{$\begin{array}{l}\text { Ration } \\
\text { Sex } \\
\text { Observations }\end{array}$} & \multirow{3}{*}{$\begin{array}{c}\text { Milk replacer } \\
\text { Male } \\
14\end{array}$} & \multicolumn{3}{|c|}{ Maize silage/concentrate } & \multirow{3}{*}{$\begin{array}{l}\text { SEM } \\
11(15)\end{array}$} \\
\hline & & Male & & Female & \\
\hline & & 11 & (15) & 15 & \\
\hline Blood haemoglobin $(\mathrm{g} / 100 \mathrm{~mL})$ & $10.9^{\circ}$ & $12.8^{\mathrm{n}}$ & $(12.7)$ & $13.1^{\mathrm{a}}$ & $0.45(0.40)$ \\
\hline Iron (mg/kg M.l.d.) & $5.81^{\mathrm{b}}$ & $8.73^{\mathrm{a}}$ & $(8.97)$ & $8.87^{n}$ & $0.03(0.03)$ \\
\hline Pigments (mg/kg M.l.d.) & $69^{c}$ & $103^{b}$ & $(103)$ & $114^{a}$ & $3.85(4.49)$ \\
\hline
\end{tabular}

TExplanations see footnotes in Table 3

In contrast to the haematological status, differences in muscle iron content were far more pronounced (Table 4). This confirms the presence of a wide difference in metabolically available iron between the two feeding alternatives since the phenomenon of homeostasis effectively reduces the response to different oral and parenteral iron supply on iron concentrations in muscle (KREUZER and KIRCHGESSNER, 1991). Also a higher iron supplementation of milk replacers elevates muscle iron. When iron content of milk replacer was elevated from 10 to 100 
$\mathrm{mg} \mathrm{Fe} / \mathrm{kg}$, FREUDENREICH et al. (1979) found quite a linear increase from 6.0 to 9.1 $\mathrm{mg} \mathrm{Fe} / \mathrm{kg} \mathrm{M.1.d.,} \mathrm{which} \mathrm{is} \mathrm{in} \mathrm{the} \mathrm{range} \mathrm{found} \mathrm{in} \mathrm{the} \mathrm{present} \mathrm{study.} \mathrm{With} \mathrm{muscle} \mathrm{iron}$ concentrations of 3.1 and $7.7 \mathrm{mg} / \mathrm{kg}$ DUFEY (1991) reported relatively lower values at average haemoglobin concentrations of 7.2 and $12.7 \mathrm{~g} / 100 \mathrm{ml}$. Somewhat lower iron concentrations in M.l.d. than found in this study were also reported by MILTENBURG et al. (1992) and POMMIER et al. (1995), but the concentrations nevertheless depended on oral iron intake.

Pigment concentration in M.l.d. was as clearly influenced as iron content, with the MSC females showing the significantly highest values (Table 4). Pigment content was closely correlated with muscle iron $(r=0.8)$. Since pigmentation is mainly determined by haeme iron (myoglobin), a close relationship was expected and also found in other studies (e.g., FREUDENREICH et al., 1979; POMMIER et al., 1995).

\subsection{Meat colour}

Meat from MSC calves of both sexes was found to be darker than the milk replacer fed control by on average about one class of the Dutch colour standard and showed at every point in time and in both muscles significantly lower lightness ( $\mathrm{L}^{*}$ ) and more intensive redness $\left(\mathrm{a}^{*}\right)$ compared with the control (Table 5). Particularly the ranges of the $a^{*}$ values of the two feeding treatments hardly overlapped (Fig.). Hue angle indicated for MSC calves a colour inclining more to purple, and chroma showed that their meat colour was overall clearly higher saturated. These colour differences may be attributed to the different iron and pigment concentration since a similar response on increased iron supply was found in another study (MAC DOUGALL et al., 1973). It seems noteworthy that, according to measurements carried out under the same conditions with the same equipment, lightness and redness of the aged M.l.d. of the MSC calves was already very close to the colour of M.1.d. found in very young intensively fattened heifers (GERHARDY, 1995; SCHEEDER et al., 1996) or even 13 months old young bulls (SCHEEDER, 1998). However, meat was still quite different in colour from that of bulls fattened to usual carcass weights (KREUZER et al., 1995). The differences in yellowness were less pronounced with only slightly higher values for the MSC calves in M.1.d. compared to control. In M.r.a. yellowness changed considerably from $45 \mathrm{~min}$ p.m. to $24 \mathrm{~h}$ p.m. which also led to a drastic change in hue angle. The colour standard applied to facilitate visual judgement obviously fitted better to the colour of M.r.a. at $24 \mathrm{~h}$ than at $45 \mathrm{~min} \mathrm{p.m}$. but neither the stated nor the measured $L * a * b *$ values of the various classes of the standard (Table 2) did really match the actual colour of M.r.a. Generally, the colour turned to more light and intense in M.r.a. during the first day after slaughter and in M.l.d. during ageing for 14 days. These findings are well supported by DUFEY (1987) who also found an increase in lightness of veal due to ageing of 14 days. The changes in M.1.d. redness and chroma during ageing were less pronounced in control calves than in MSC calves, leading to even greater treatment differences in the aged meat. Red veal was also reported to be more susceptible to discoloration than white veal (FAUSTMAN et al., 1992; GARIÉPY et al., 1998) but discoloration was not observed in this study. 
Table 5

Meat colour of calves fattened according to different feeding schedules (Fleischfarbe von Kälbern aus verschiedenen Fütterungssystemen) ${ }^{\prime}$

\begin{tabular}{|c|c|c|c|c|c|}
\hline \multirow{3}{*}{$\begin{array}{l}\text { Ration } \\
\text { Sex } \\
\text { Observations }\end{array}$} & \multirow{3}{*}{$\begin{array}{l}\text { Milk replacer } \\
\text { Male } \\
14 \\
\end{array}$} & \multicolumn{3}{|c|}{ Maize silage/concentrate } & \multirow{3}{*}{$\begin{array}{l}\text { SEM } \\
11(15)\end{array}$} \\
\hline & & \multicolumn{2}{|c|}{ Male } & \multirow{2}{*}{$\begin{array}{c}\text { Female } \\
15\end{array}$} & \\
\hline & & 11 & $(15)$ & & \\
\hline \multicolumn{6}{|c|}{ IVO-DLO colour grades (M, rectus abdominis) ${ }^{2}$} \\
\hline 45 min p.m. & $3.0^{\mathrm{b}}$ & $4.0^{2}$ & $(4.0)$ & $4.0^{\mathrm{a}}$ & $0.17(0.19)$ \\
\hline 24 h p.m. & $2.6^{\mathrm{b}}$ & $3.5^{\mathrm{a}}$ & $(3.5)$ & $3.7^{\mathrm{a}}$ & $0.14(0.17)$ \\
\hline \multicolumn{6}{|c|}{ Lightmess $\left(\mathrm{a}^{*}\right)$} \\
\hline \multicolumn{6}{|c|}{ M. rectus abdominis } \\
\hline $45 \mathrm{~min}$ p.m. & $41.7^{\circ}$ & $38.0^{\mathrm{b}}$ & $(38.2)$ & $37.4^{b}$ & $0.41(0.47)$ \\
\hline 24 h p.m. & $43.7^{2}$ & $39.8^{b}$ & $(39.8)$ & $40.0^{\mathrm{b}}$ & $0.39(0.46)$ \\
\hline \multicolumn{6}{|c|}{ M. longissimus dorsi } \\
\hline 26 h p.m. & $44.1^{2}$ & $40.6^{\mathrm{b}}$ & $(39.6)$ & $40.2^{b}$ & $0.61(0.71)$ \\
\hline $14 \mathrm{~d}$ p.m. & $47.3^{a}$ & $45.2^{\mathrm{bb}}$ & (43.1) & $44.6^{b}$ & $0.57(0.67)$ \\
\hline \multicolumn{6}{|c|}{ Redness ( $a^{*}$ ) } \\
\hline \multicolumn{6}{|c|}{ M. rectus abdominis } \\
\hline $45 \mathrm{~min}$ p.m. & $8.1^{\mathrm{b}}$ & $10.9^{a}$ & $(11.0)$ & $10.5^{a}$ & $0.26(0.30)$ \\
\hline 24 h p.m. & $11.1^{\mathrm{b}}$ & $14.5^{\circ}$ & (14.2) & $14.3^{3}$ & $0.52(0.61)$ \\
\hline \multicolumn{6}{|c|}{ M. longissimus dorsi } \\
\hline 26 h p.m. & $12.3^{\mathrm{b}}$ & $14.6^{a}$ & (14.5) & $15.6^{\mathrm{a}}$ & $0.61(0.72)$ \\
\hline 14 d p.m. & $13.0^{\mathrm{b}}$ & $17.5^{a}$ & (16.1) & $17.4^{\mathrm{a}}$ & $0.50(0.58)$ \\
\hline \multicolumn{6}{|c|}{ Yellowness $\left(b^{*}\right)$} \\
\hline \multicolumn{6}{|c|}{ M. rectus abdominis } \\
\hline 45 min p.m. & $1.8^{\mathrm{a}}$ & $2.0^{2}$ & (1.9) & $1.6^{\mathrm{a}}$ & $0.22(0.26)$ \\
\hline 24 h p.m. & $6.4^{2}$ & $6.6^{\circ}$ & (6.3) & $6.1^{2}$ & $0.52(0.61)$ \\
\hline \multicolumn{6}{|c|}{ M. longissimus dorsi } \\
\hline 26 h p.m. & $7.5^{\mathrm{b}}$ & $8.2^{\mathrm{ab}}$ & (7.9) & $8.8^{\mathrm{a}}$ & $0.37(0.43)$ \\
\hline 14 d p.m. & $8.9^{b}$ & $10.9^{\circ}$ & (9.3) & $10.6^{2}$ & $0.31(0.36)$ \\
\hline \multicolumn{6}{|c|}{ Hue angle } \\
\hline \multicolumn{6}{|c|}{ M. rectus abdominis } \\
\hline $45 \mathrm{~min}$ p.m. & $12.5^{\mathrm{a}}$ & $9.9^{\mathrm{b}}$ & $(9.5)$ & $8.6^{b}$ & $1.30(1.52)$ \\
\hline 24 h p.m. & $29.2^{2}$ & $24.0^{\mathrm{b}}$ & (23.2) & $22.3^{b}$ & $1.33(1.55)$ \\
\hline \multicolumn{6}{|c|}{ M. longissimus dorsi } \\
\hline 26 h p.m. & $31.7^{\mathrm{a}}$ & $29.2^{\mathrm{b}}$ & $(28.6)$ & $29.3^{b}$ & $0.42(0.49)$ \\
\hline 14 d p.m. & $34.7^{\mathrm{a}}$ & $31.9^{\mathrm{b}}$ & $(29.2)$ & $31.3^{b}$ & $0.49(0.57)$ \\
\hline \multicolumn{6}{|c|}{ Chroma } \\
\hline \multicolumn{6}{|c|}{ M. rectus abdominis } \\
\hline $45 \mathrm{~min}$ p.m. & $8.3^{\mathrm{b}}$ & $11.1^{\mathrm{n}}$ & $(11.2)$ & $10.7^{\mathrm{a}}$ & $0.27(0.31)$ \\
\hline 24 h p.m. & $13.0^{\circ}$ & $16.1^{\circ}$ & $(15.7)$ & $15.6^{\mathrm{a}}$ & $0.66(0.76)$ \\
\hline \multicolumn{6}{|c|}{ M. longissimus dorsi } \\
\hline 26 h p.m. & $14.4^{\mathrm{b}}$ & $16.8^{\mathrm{a}}$ & $(16.5)$ & $18.0^{\mathrm{a}}$ & $0.49(0.57)$ \\
\hline 14 d p.m. & $15.7^{b}$ & $20.6^{\mathrm{a}}$ & (18.7) & $20.3^{a}$ & $0.56(0.66)$ \\
\hline
\end{tabular}

${ }^{2}$ lelight pink; $5=$ dark red

Differences in colour traits between male and female MSC calves were found to be low, but results were confounded with breed of the animals. The slightly higher contents of blood haemoglobin, muscle iron and muscle pigment in the females, however, are consistent with the results of MOREL (1996) who also observed higher 
haemoglobin contents in female calves and reported more frequent objections against colour of veal originating from females.
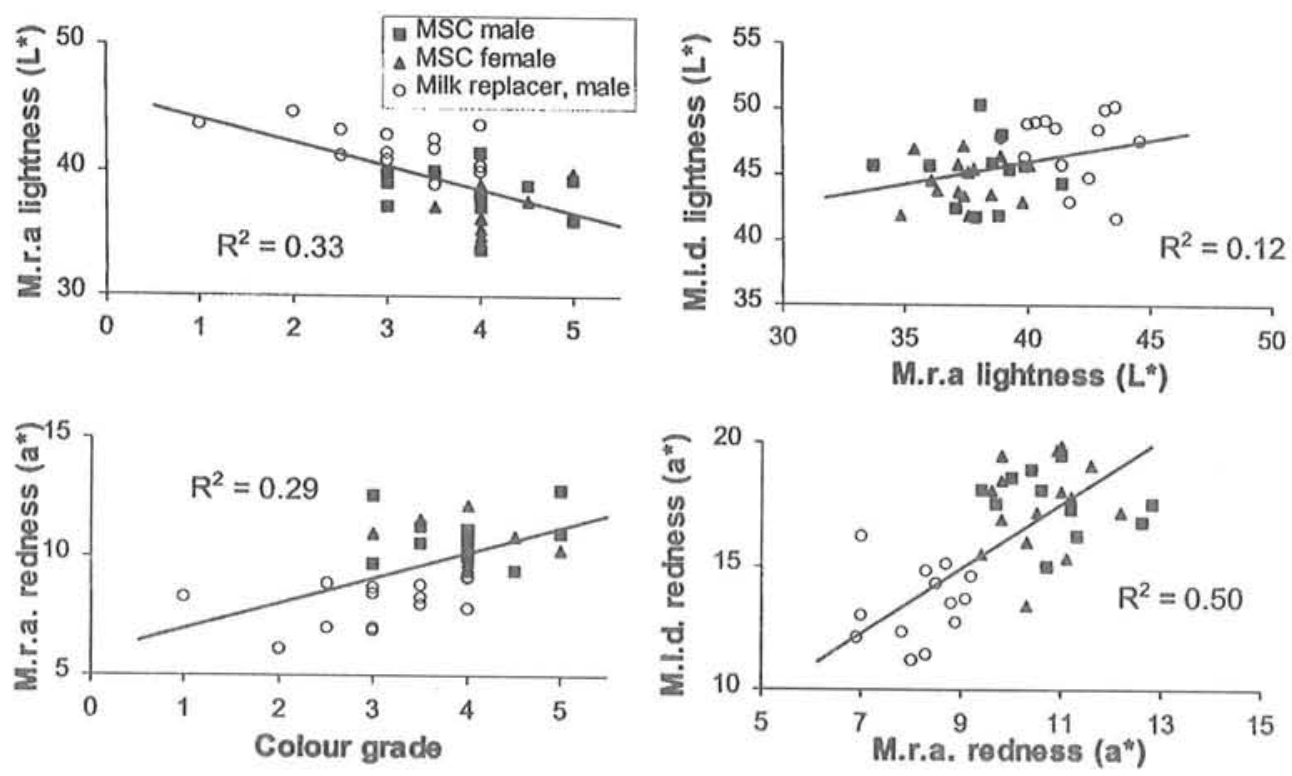

Fig: Regression of $L^{*}$ and $a^{*}$ in M.r.a. on standard assisted colour grading at $45 \min$ p.m. (left) and of $L^{*}$ and $a^{*}$ in $14 \mathrm{~d}$ aged M.l.d. on $\mathrm{L}^{*}$ and $\mathrm{a}^{*}$ in M.r.a. at $45 \mathrm{~min}$ p.m. (right) in maize silage concentrate (MSC) and solely milk replacer fed calves (Regression von $\mathrm{L}^{*}$ bzw. a* im M.r.a. $45 \mathrm{~min}$ p.m. auf die skalenunterstützte Farbklassifizierung (links) sowie von $L^{*}$ bzw. $a^{*}$ im 14 Tage gereiftem M.l.d. auf L* bzw. a* im M.r.a. 45 min p.m. (rechts) bei mit Maissilage und Kraftutter (MSC) oder nur mit Milchaustauscher gefutterten Kälbern)

Apart from dietary iron several other effects on veal colour, particularly concerning the pre- and post-slaughter treatment like transport and lairage conditions, electrical stimulation and rate of cooling, are discussed. As all the animals were treated in the same way with respect to these effects, no influence or interaction of such effects was assumed for this study. However, since the $\mathrm{L}^{*} \mathrm{a} \mathrm{b}^{*}$ values and, consequently, chroma were lower in aged M.l.d. when animals showing DFD were included (Table 5, values in brackets), $\mathrm{pH}$ obviously had a major effect. This is probably due to the increased light absorption of the 'open' meat structure at high $\mathrm{pH}$ and is confirmed by a study of GUIGNOT et al. (1994). In contrast, hardly any changes were observed in M.r.a. colour of MSC males when DFD expressing animals were excluded, indicating that identification of DFD is not possible by using early p.m. colour grading or measurement.

\subsection{Meat quality apart from colour}

The incidence of DFD was surprisingly high in the MSC male calves (4 out of 15) compared with none in the conventionally fattened group as well as in the MSC 
females. Furthermore, even excluding these animals, $\mathrm{pH}$ at $24 \mathrm{~h}$ and 14 days p.m. remained numerically higher in the MSC males (Table 6). DFD is described as a common problem in bulls (MATZKE et al., 1985) but its incidence is normally very low in calves fed exclusively on milk replacer (DUFEY, 1987) unless artificially induced (GUIGNOT et al., 1994). The high rate of DFD and the overall slightly elevated $\mathrm{pH}$ in the MSC males may indicate that these animals had already developed a typical ruminant metabolism characterised by low blood glucose levels. It is, furthermore, well known that sexual mature bulls are particularly susceptible to develop DFD. It remains matter of conjecture whether dietary effects may influence sexual development by means of a delayed maturation with pure milk or milk replacer diets or whether higher glycogen stores or the faster supply of glucose in the purely milk fed calves might serve as an explanation for the lower ultimate $\mathrm{pH}$. As a consequence, special emphasis should be put on transport and lairage conditions in order to avoid DFD when a forage/concentrate feeding system is used for veal production.

Table 6

Chemical composition and meat quality traits in the $M$. longissimus dorsi of calves fattened according to different feeding schedules (Chemische Zusammensetzung und Merkmale der Fleischqualität des $M$. longissimus dorsi von Kälbern aus verschiedenen Fütterungssystemen)'

\begin{tabular}{|c|c|c|c|c|c|}
\hline \multirow{3}{*}{$\begin{array}{l}\text { Ration } \\
\text { Sex } \\
\text { Observations }\end{array}$} & \multirow{3}{*}{$\begin{array}{l}\text { Milk replacer } \\
\text { Male } \\
14\end{array}$} & \multicolumn{3}{|c|}{ Maize silage/concentrate } & \multirow{3}{*}{$\begin{array}{l}\text { SEM } \\
11(15)\end{array}$} \\
\hline & & \multicolumn{2}{|c|}{ Male } & \multirow{2}{*}{$\begin{array}{c}\text { Female } \\
15\end{array}$} & \\
\hline & & 11 & (15) & & \\
\hline \multicolumn{6}{|l|}{$\mathrm{pH}$} \\
\hline 26 h p.m. & $5.50^{\mathrm{a}}$ & $5.58^{\mathrm{a}}$ & $(5.69)$ & $5.53^{4}$ & $0.02(0.03)$ \\
\hline aged for $14 d$ & $5.53^{\mathrm{a}}$ & $5.58^{\mathrm{a}}$ & $(5.72)$ & $5.53^{\circ}$ & $0.02(0.02)$ \\
\hline \multicolumn{6}{|c|}{ Chemical composition (\%) } \\
\hline Dry matter & $23.4^{\mathrm{b}}$ & $23.6^{\mathrm{b}}$ & $(23.4)$ & $23.8^{\circ}$ & $0.08(0.10)$ \\
\hline Fat & $0.83^{b}$ & $1.08^{\mathrm{a}}$ & $(1.09)$ & $1.24^{\circ}$ & $0.07(0.09)$ \\
\hline Collagen & $1.78^{\mathrm{b}}$ & $2.08^{\circ}$ & $(2.10)$ & $1.71^{\mathrm{b}}$ & $0.04(0.05)$ \\
\hline Collagen solubility (\%) & $21.9^{\mathrm{b}}$ & $23.9^{a}$ & $(24.2)$ & $21.3^{b}$ & $0.32(0.37)$ \\
\hline Cooking loss (\%) & $29.0^{\mathrm{a}}$ & $28.9^{a}$ & $(27.8)$ & $28.7^{\circ}$ & $0.44(0.51)$ \\
\hline \multicolumn{6}{|c|}{ Warner Bratzler shear values } \\
\hline Maximum force $(\mathrm{N})$ & $49.1^{*}$ & $41.7^{2}$ & $(38.3)$ & $45.3^{\circ}$ & $3.57(4.16)$ \\
\hline Extension (mm) & $14.8^{\mathrm{a}}$ & $14.8^{\mathrm{a}}$ & (15.0) & $14.7^{\mathrm{a}}$ & $0.24(0.27)$ \\
\hline
\end{tabular}

'Explanations see footnotes in Table 3

It is well known that DFD meat expresses a high water holding and binding capacity. Accordingly, cooking loss was slightly lower for MSC males only when DFD samples were included but was not influenced by feeding when DFD was excluded (Table 6). Also GARIÉPY et al. (1998) found no difference in drip and cooking loss of veal between grain and milk fed calves.

The results of chemical analyses of M.l.d. showed some significant effects of the feeding treatment. Intramuscular fat content and, consequently, dry matter content were higher in the MSC calves, particular in females. This corresponds to the higher fatness scores and may also be partly attributed to an effect of sex. The low intra- 
muscular fat content of the control calves seems to be typical for conventional veal, as very similar values were reported by FREUDENREICH et al., (1981) for M.l.d. of conventionally reared calves with carcass weights up to $117 \mathrm{~kg}$ on average.

Content and solubility of collagen were highest for MSC males compared with the two other groups. According to the results of JEREMIAH and MARTIN (1982) a higher collagen content and a lower solubility may be expected in female compared with male cattle. This suggests that the MSC treatment led to an increased collagen content, which was concomitantly accompanied by a higher solubility. GARIÉPY et al. (1998) also described a coarse texture of veal from grain fed calves compared to milk replacer fed calves. As this effect was no longer evident when the grain diet was supplemented with iron chelating EDTA, the authors assumed an EDTA effect on the perimysial connective tissue. A high solubility of the collagen might be one of the most important characteristic of veal because this criterion, which is highly age dependent (NAKANO and THOMPSON, 1980), enables a clear differentiation between beef categories (GERHARDY, 1995) and may substantially contribute to meat texture, particularly in cuts which are rich in connective tissue (SCHEEDER, 1992). In this study, however, the higher solubility of collagen of MSC males was obviously counterbalanced to a certain degree by its higher content, as no significant effect on instrumental texture, particularly on the extension, was found and maximum shear force was only numerically lower for MSC males. On the other hand, sensory analysis revealed a significantly higher tenderness for MSC males compared with control (Table 7). Only a small part of the higher tenderness can be explained with a higher ultimate $\mathrm{pH}$ (GUIGNOT et al., 1994), since in the present study all DFD samples had been excluded from sensory analyses. It seems more likely that the higher supply of iron and the dietary induced physiological changes towards a ruminating organism, associated by a shift in nutrient absorption from carbohydrates to volatile fatty acids, might have been effective. This might have influenced the development of structural characteristics of the muscles at this early stage of growth bearing consequences also on post mortem muscle metabolism. Results from other investigations also indicate that tenderness of veal remains widely unaffected when only iron supply is varied (FREUDENREICH et al., 1979; DUFEY, 1991; OLIVER et al., 1997) whereas with the introduction of feeds other than milk replacer certain effects can be expected (QUILICHINY, 1989; GARIÉPY et al., 1998).

Additionally to tenderness, the MSC males were superior to the control in juiciness and acceptance whereas flavour did not significantly differ between groups (Table 7). In contrast, iron supply alone increased flavour intensity and preference against veal from iron-deficient calves in a study of DUFEY (1991) or led to a more intense beef flavour when combined with grain feeding (GARIÉPY et al., 1998). Overall, meat of MSC males was preferred in $76 \%$ of the comparisons. The corresponding value for the conventional veal was $14 \%$, and $10 \%$ of the comparisons remained undecided. Similarly, veal from calves fed on a corn diet was ranked better than veal from milk replacer-fed calves (QUILICHINY, 1989). 
Table 7

Sensory grading of $M$. longissimus dorsi from male calves fattened according to different feeding schedules (Sensorische Einstufung des $M$. longissimus dorsi von männlichen Kälbern aus aus verschiedenen Fütterungssystemen)'

\begin{tabular}{lcccc}
\hline $\begin{array}{l}\text { Ration } \\
\text { Observations }\end{array}$ & $\begin{array}{c}\text { Milk replacer } \\
5 \times 10\end{array}$ & & $\begin{array}{c}\text { Maize silage/concentrate } \\
5 \times 10\end{array}$ & SD $^{2}$ \\
\hline Tenderness $^{3}$ & 5.4 & $*$ & 6.3 & 1.6 \\
Juiciness $^{3}$ & 4.6 & $* * *$ & 5.4 & 2.1 \\
Flavour $^{3}$ & 5.2 & n.s. & 5.6 & 1.4 \\
Off-flavour $^{3}$ & 6.9 & n.s. & 6.9 & 0.6 \\
Acceptance $^{4}$ & 4.8 & $* * *$ & 5.7 & 1.8 \\
\hline
\end{tabular}

Teast square means; difference is unequal zero in pairwise comparison with $\mathrm{P}<0.05,0.01$ and 0.001 when marked with ${ }^{\circ}$, and ${ }^{* 0}$, respectively

${ }^{2}$ Standard deviation of the difference

'I=extremely tough, dry, weak; 8=extremely tender, juicy, intense

$4 \mathrm{l}=$ unacceptable; $8=$ extremely desirable

\subsection{Suitability of rapid veal colour assessment methods}

One option for rapid assessment of veal colour is given by haematological traits, which can be already measured in the still living animals and were shown to correlate with meat colour (CHARPENTIER, 1970; MILTENBURG et al., 1992; BARNIER et al., 1998). Another approach is the assessment of colour or colour-related traits, which can be visually judged or measured with invasive or non-invasive instruments at an earlypost mortem stage without being forced to dissect valuable carcass parts (EIKELENBOOM et al., 1992). Correlation was 0.61 between blood haemoglobin, measured two weeks before slaughter, and lightness $\left(\mathrm{L}^{*}\right)$ of M.r.a. in the investigation of BARNIER et al. (1998). Haemoglobin obtained at the last day before slaughter correlated with visual flank muscle colour score at a level of 0.54 in the study of WILSON et al. (1995). In the present study, haemoglobin was measured with a rapid method. The correlations to several veal colour characteristics were much lower than reported in literature or even not existing at all (Table 8). Considering the correlations described in the studies mentioned above, this may in part be attributed to the inaccuracy of the rapid method rather than to a lack of relationship among blood haemoglobin and veal colour. However, analysing haemoglobin with the usual laboratory method is time-consuming and the correlations reported are still low questioning its predictive value for veal colour.

Early on-line measurements of veal colour can be carried out using invasive probes or applying colour measurements in muscles directly accessible at the surface of the carcass like the M.r.a. Optical devices like the fibreoptical insertion probe (FOP; ANDERSEN et al., 1993), which could be easily applied in the slaughter process, have the disadvantage of restrictions in wave-length and a transfer into the CIE units is not possible (SYBESMA, 1993). The same is valid for the Fat-o-Meat'er (FOM) reflectance value. These techniques therefore do not allow for a differentiated recording of colour characteristics such as lightness and redness.

The M.r.a. is most often used for direct early colour assessment (e.g. BARNIER et al., 1998; OLIVER et al., 1997) although MILTENBURG et al. (1992) used the M. semi- 
Table 8

Correlations among veal colour-related traits (Korrelationen zwischen Merkmalen der Kalbfleischfarbe) ${ }^{1}$

\begin{tabular}{|c|c|c|c|c|c|c|c|}
\hline & \multirow{2}{*}{\multicolumn{2}{|c|}{$\begin{array}{l}\text { Haemo- Iron content } \\
\text { globin (M.l.d.) } \\
\text { content }\end{array}$}} & \multirow[t]{2}{*}{$\begin{array}{l}\text { Pigments } \\
\text { (M.l.d.) }\end{array}$} & \multicolumn{2}{|c|}{$\begin{array}{c}\text { M.r.a. } \\
\text { (45 min p.m.) }\end{array}$} & \multicolumn{2}{|c|}{$\begin{array}{l}\text { M.r.a. } \\
\text { (24 h p.m.) }\end{array}$} \\
\hline & & & & $\mathrm{L}^{*}$ & $a^{*}$ & $\mathrm{~L}^{*}$ & $\mathrm{a}^{*}$ \\
\hline Iron content (M.l.d.) & 0.28 & & & & & & $=$ \\
\hline $\begin{array}{l}\text { Pigments (M.l.d.) } \\
\text { M.r.a. ( } 45 \text { min. p.m.) }\end{array}$ & $0.32^{\text {* }}$ & $0.80^{\text {훈 }}$ & & & & & \\
\hline $\begin{array}{l}\text { M.r.a. (45 min. p.m.) } \\
-L^{\star *}\end{array}$ & -0.16 & $-0.57 * * *$ & $-0.71^{\text {t*k* }}$ & & & & \\
\hline $\begin{array}{l}\text { - a } \\
\text { M.r.a. (24 h p.m.) }\end{array}$ & 0.15 & $0.66^{* * \hbar *}$ & 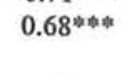 & $-0.70^{\text {*⿻三丨 }}$ & & & \\
\hline$-L^{*}$ & -0.06 & $-0.56^{* * *}$ & $-0.52^{\text {केष* }}$ & $0.71^{* * *}$ & $-0.69 * * *$ & & \\
\hline $\begin{array}{l}-\mathrm{a}^{\mathbf{\phi}} \\
\text { M.l.d. (26 h p.m.) }\end{array}$ & 0.10 & $0.54^{* b *}$ & 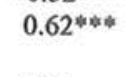 & $-0.64^{* m^{*}}$ & $0.62^{* \omega *}$ & $-0.40^{*}$ & \\
\hline$-L^{*}$ & $-0.37 *$ & -0.53 * क* & -0.31 & $0.32^{*}$ & $-0.38 *$ & 0.28 & $-0.43 * *$ \\
\hline $\begin{array}{l}-a^{*} \\
\text { M.I.d. (14 d p.m.) }\end{array}$ & 0.07 & 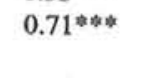 & $0.70^{\text {th }}$ & $-0.45^{\text {क }}$ & $0.44^{\text {क }}$ & $-0.47^{* *}$ & 0.31 \\
\hline$-L^{*}$ & $-0.33^{*}$ & $-0.64 * * *$ & $-0.42 * *$ & $0.34^{*}$ & $-0.29 * *$ & 0.26 & -0.28 \\
\hline$-a^{*}$ & $0.35^{*}$ & $0.89^{* * *}$ & $0.80^{\text {***}}$ & $-0.58^{*+\ldots+}$ & $0.71^{* *}$ & $-0.59^{* * *}$ & $0.54^{* * * *}$ \\
\hline
\end{tabular}

tendinosus which is not as easy accessible, because it must be cleared from covering adipose and connective tissue. Visual classification may be markedly improved when a standardised scale is used (SYBESMA, 1993). BARNIER et al. (1998) reported a correlation of 0.6 between colour of M.r.a. visually assessed at $45 \mathrm{~min}$ p.m. by a standard-scale assisted ten grade judgement (light - dark) with $\mathrm{L}^{*}$ values measured in the same muscle. In the present study, however, the scale-assisted colour grading was for several reasons only poorly related to the results of the instrumental measurements (Fig.). One explanation may be that the grading persons were not experienced and the recommended standard light source (Philips TL 57) was not available. Another constraint of the used scale is its limitation to five classes. This problem may be overcome to some extent when intermediate classes are also assigned, which was not done in this study. Apart from that, it was quite difficult to perform a concise visual judgement, as the standard used did not closely match the actual colour of M.r.a., particularly at $45 \mathrm{~min}$ p.m. (Tables 2 and 5).

For these reasons, the use of the Minolta Chroma-Meter was advantageous. This noninvasive technique yields objective values and allows for differentiated measurement of colour, recording lightness, redness and yellowness in the CIE system. The value of the early colour assessment, however, depends not only on the method applied but on the correlation between this measure and the actual colour of the veal ready for sale. In our investigation, the correlations of colour traits of M.r.a. at $45 \mathrm{~min}$ p.m. and the respective traits of aged M.l.d. were found to be significant but not as close as desired (Table 8, Fig.). The highest correlation was found for redness, but this has also to be attributed to a large extent to the high overall variability due to the treatment effects and therefore is not fully reliable. On the other hand it can be seen that a clear differentiation between the feeding treatments was possible using the $\mathrm{a}^{*}$ value in M.r.a. at 45 min (Fig.). Redness is obviously the most important colour trait to distinguish 
between different classes of veal and might therefore be a key issue for marketing of pink veal.

\section{Conclusions}

The use of silage and concentrate based rations in veal production obviously changes metabolism of the calves to a large extent, which meets the concern of animal welfare when heavy veal calves are produced, but also increases the susceptibility to develop DFD meat as a consequence of pre-slaughter stress. A feeding system like this may also lead to slightly less well conformed carcasses and clearly darker, particularly redder, veal, a difference which is already obvious at an early post mortem stage. Meat quality by means of chemical composition, collagen solubility, texture and even sensory perception could remain unaffected or be even superior to conventionally produced veal. This again questions the decisive function of colour for veal quality judgement. It seems to be necessary to define other veal characteristics which better describe its specific quality by means of texture and flavour. In the present situation, a successful use of concentrates and forage in veal production will still depend on commercial conditions including acceptance of traders and consumers.

\section{References}

ANDERSEN, J.R.; OVESEN, E.; BORGGAARD, C.:

Improved methods of carcass and meat quality estimation. In: Abstr. $44^{\text {th }}$ Ann. Meet. EAAP, Vol. II, Aarhus, Denmark, 16-19 August 1993, contribution C3.7 (1993), 42-43

ANONYMUS:

3. Verordnung über gesetzliche Handelsklassen für Rindfleisch. Bundesgesetzblatt Teil I, Bonn, Germany (1991), 2388-2390

BARNIER, V.M.H.; KLONT, R.E.; VAN DIJK, A.; EIKELENBOOM, G.; HOVING BOLINK, A.H.; SMULDERS, F.J.M.:

Post mortem variation in $\mathrm{pH}$, temperature and colour profiles of electrically stimulated veal carcasses in relation to preslaughter blood haemoglobin content. In: Meat Consumption and Culture. Proc. 44th Int. Cong. Meat Science and Technology (ICoMST). A. Diestreand and J.M. Monfort (Editors), Barcelona (1998), 496-497

BAUSCHMID, M.; EICHINGER, H.; KROMKA, F.:

Rindfleischqualität im Urteil der Verbraucher. Fleischwirtsch. 62 (1992), 1411-1414

BEAUCHEMIN, K.A.; LACHANCE, B.; ST.-LAURENT, G.:

Effects of concentrate diets on performance and carcass characteristics of veal calves. J. Anim. Sci. 68 (1990), 35-44

BERNIER, J.F.; FILLION, F.J.; BRISSON, G.J.:

Dietary fibers and supplementary iron in a milk replacer for veal calves. J. Dairy Sci. 67 (1984), 23692379

BOEHNCKE, E.; GROPP, J.:

Zur Eisenversorgung des Mastkalbes. 1. Mitt.: Beurteilung der Eisenversorgung (Literaturübersicht). Bayer. Landwirtsch. Jb. 56 (1979), 571-593

BUNDESKANZLEI (Editor): Futtermittel. Eidgenössische Drucksachen- und Materialzentrale, 3000 Bern, Switzerland (1995)

CHARPENTIER, J.:

Early diagnosis of the meat color of veal. J. Anim. Sci. 31 (1970), 1099-1101

DLG (DEUTSCHE LANDWIRTSCHAFTSGESELLSCHAFT): DLG-Futterwerttabellen. Mineralstoffgehalte in Futtermitteln, $2^{\text {nd }}$ ed., DLG-Verlag, Frankfurt/Main (1973) 
DUFEY, P.-A.:

6. Die Fleischqualität der Kälber. In: Die Fleischleistung der schweizerischen Rinderrassen: Ergebnisse der Kälber- und Munischlachtungen im Projekt Rindfleisch. Schriften der Schweizerischen Vereinigung

DUFEY, P.-A.: für Tierzucht 69 (1987), 29-38

Eisenversorgung beim Mastkalb. Teil II: Vergleich der Fleischqualität von anämischen und nichtEGGER. I: anämischen Kälbern. Landwirtsch. Schweiz 4 (1991), 89-92

Eisenversorgung beim Mastkalb. Teil 1: Einfluss zweier Eisen- und Kupferdosierungen auf Leistung, Gesundheit und Fleischfarbe beim Mastkalb. Landwirtsch. Schweiz 4 (1991), 41-46

EIKELENBOOM, G.; HOVING-BOLINK, A.H.; HULSEGGE, B.:

Evaluation of invasive instruments for assessment of veal colour at time of classification. Meat Sci. 31 (1992), 343-349

FAUSTMAN, C., YIN, M.C.; NADEAU, D.B.:

Color stability, lipid stability, and nutrient composition of red and white veal. J. Food Sci. 57 (1992), 302-304, 311

FREUDENREICH, P.; KÜHNE, D.; SCHÖN, L.; SCHOLZ, W.:

Zur Eisenversorgung des Mastkalbes. 4. Mitteilung: Gewebebeschaffenheit von Kalbfleisch bei unterschiedlicher Eisenversorgung. Bayer. Landwirtsch. Jb. 56 (1979), 618-623

FREUDENREICH, P.; SCHÖN, L.; SCHEPER, J.:

Untersuchungen über die Beschaffenheit von Kalb- und Jungbullenfleisch. 2. Mitteilung: Grillverlust, Zartheit, Sensorik und Vollanalyse. Fleischwirtsch. 61 (1981), 1043-1048

GARIÉPY, C.; DELAQUIS, P.J.; POMMIER, S.; DE PASSILLÉ, A.-M.B.; FORTIN, J.; LAPIERRE, H.: Effect of calf feeding regimes and diet EDTA on physico-chemical characteristics of veal stored under modified atmospheres. Meat Sci. 49 (1998), 101-115

GERHARDY, H.: Quality of beef from commercial fattening systems in Northern Germany. Meat Sci. 40 (1995), 103-120

GUIGNOT, F.; TOURAILLE, C.; OUALI, A.; RENERRE, M.; MONIN, G.:

Relationships between post-mortem pH changes and some traits of sensory quality in veal. Meat Sci. 37 (1994), 315-325

GYGAX, M.; HIRNI, H.; BLUM, J.:

Mastleistung und Fleischfarbe bei Kälbern in Abhängigkeit von der Eisenzufuhr. J. Anim. Physiol. HILL, F.: Anim. Nutr. 64 (1990), 20-21

The solubility of intramuscular collagen in meat animals of various ages. J. Food Sci. 31 (1966), 161166

HORNSEY, H.C.:

The colour of cooked cured pork. I. - Estimation of the nitric oxide-haem pigments. J. Sci. Fd. Agric. 7 (1956), 534-540

JEREMIAH, L.E.; MARTIN, A.H.:

The influence of breed of sire and sex on bovine intramuscular collagen content and solubility after various intervals of postmortem aging. Can. J. Anim. Sci. 62 (1982), 77-84

KNAUS, W.; ZOLLITSCH, W.; LETTNER, F.; SCHLERKA, G.; PANGERL, R.:

Effects of iron supplementation on the performance, blood hemoglobin, iron concentration and carcass color of veal calves. Die Bodenkultur 48 (1997), 43-51

KREUZER, M.; KIRCHGESSNER, M.: Iron retention in tissues and carcass of rats during growth and under different oral and parenteral supply of iron as Fe(III)-hydroxide-polymaltose. J. Anim. Physiol. Anim. Nutr. 65 (1991), 96-109

KREUZER, M.; GERHARDY, H.; OSSOWSKI, D.; VOSS, G.E.M.: Improved storage and dietetic properties of carcass fat tissues in growing Holstein as well as Charolais x Holstein bulls fed full-fat rapeseed. Arch. Tierz., Dummerstorf 38 (1995), 163-175

KRIPPL, J.; BURGSTALLER, G.: Vergleichende Untersuchungen über den Einfluß unterschiedlicher Haltungssysteme auf Entwicklung und Schlachtqualität von Mastkälbern. Züchtungskde., Stuttgart 42 (1970), 24-29

LINDT, F.; BLUM, J.: Occurrence of iron deficiency in growing cattle. J. Vet. Med. A 41 (1994), 237-246 
MAC DOUGALL, D.B.; BREMNER, I.; DALGARNO, A.C.:

Effect of dietary iron on the colour and pigment concentration of veal. J. Sci. Fd. Agric. 24 (1973), 1255-1263

MATZKE, P.; ALPS, H.; STRASSER, H.; GUNTER, I.:

Bullenmast unter kontrollierten Haltungs- und Schlachtbedingungen. Untersuchungen zum Auftreten und zur Beeinflussung von DFD-Fleisch durch exogene Faktoren. Fleischwirtsch. 65 (1985), 389-393

MILTENBURG, G.A.J.; WENSING, T.; SMULDERS, F.J.M.; BREUKINK, H.J.:

Relationship between blood hemoglobin, plasma and tissue iron, muscle heme pigment, and carcass color of veal. J. Anim. Sci. 70 (1992), 2766-2772

MORAN, J.; HOPKINS, A.; WARNER, R.: MOREL, I.:

The production of pink veal from dairy calves in Australia. Outlook Agric. 20 (1991), 183-190

Die Eisenversorgung beim Mastkalb. Agrarforsch. 3 (1996), 53-56

NAKANO, T.; THOMPSON, J.R.:

Age- and sex-associated changes in chemical composition of bovine triceps brachii intramuscular and epimysial connective tissue with emphasis on glycosaminoglycans. Can. J. Anim. Sci. 60 (1980), 643662

NAUMANN, K.; BASSLER, R.:

Methodenbuch. Die chemische Untersuchung von Futtermitteln. Band III, VDLUFA-Verlag, Darmstadt (1997)

NRC (NATIONAL RESEARCH COUNCIL):

Nutrient requirements of dairy cattle. $6^{\text {th }}$ rev. ed., National Academy Press, Washington D.C., USA (1988)

OLIVER, M.A.; KLONT, R.E.; BARNIER, V.M.H.; EIKELENBOOM, G.:

Meat quality characteristics of veal carcasses in relation to preslaughter blood hemoglobin content. In: Abstr. $48^{\text {th }}$ Ann. Meeting EAAP. J.A.M. van Arendonk (Editor), Wageningen Pers, Wageningen (1997), 240

POMMIER, S.A.; LAPIERRE, H.; DE PASSILLÉ, A.M.; GARIÉPY, C.:

Control of the bioavailability of iron in heavy veal production by different management systems: use of

QUILICHINY, Y.:

Influence sur la qualité bouchère de régime mixte pour veaux de boucherie. Introduction de céréales sous forme solide en substitution d'une partic de l'aliment lacté conventionnel. Viandes et Produits Carnes 10 (1989), 125-129

RENERRE, M.; TOURAILLE, C.; BORDES, P.; LABAS, R.; BAYLE, M.C.; FOURNIER, R.: Influence of straw feeding and growth-implant on veal meat quality. Meat Sci. 26 (1989), 233-244

SCHEEDER, M.R.L.:

Untersuchung der Fleischbeschaffenheit verschiedener Muskeln von Jungmastrindern. University of Göttingen. Doctoral thesis (1992)

SCHEEDER, M.R.L.:

Age-related changes in meat quality of growing cattle. In: Proc. Symp. Growth in Ruminants. Basic Aspects, Theory and Practice for the Future. J.W. Blum, T. Elsasser and P. Guilloteau (Editors). University of Berne, Switzerland, (1998) 265-275

SCHEEDER, M.R.L.; LANGHOLZ, H.-J.:

Texture properties of ten beef muscles to be marketed as steak. In: Proc. $42^{\text {nd }}$ ICoMST. Meat for the Consumer. MATFORSK (Publisher). Lillehammer, Norway (1996), 276-277

SCHEEDER, M.R.L.; GERHARDY, H.; LANGHOLZ, H.-J.:

Untersuchungen zur Verwertungseignung unterschiedlicher Muskeln weiblicher Jungmastrinder. Arch. Tierz., Dummerstorf 39 (1996), 415-429

SYBESMA, W.:

Making light of colour assessment. Meat Focus Int. 2 (1993), 211-212

WEINREICH, O.; KOCH, V.; KNIPPER, J.; EBERHARDT, W.:

Futtermittelrechtliche Vorschriften. Textsammlung mit Erläuterungen. AgriMedia im Verlag Alfred Strothe, Frankfurt/Main, Germany (1992) 
WELCHMAN, D.B.; WHELEHAN, O.P.; WEBSTER, A.J.F.:

Haematology of veal calves reared in different husbandry systems and the assessment of iron deficiency. Vet. Rec. 12 (1988), 505-510

WILSON, L.L.; EGAN, C.L.; HENNING, W.R.; MILLS, E.W.:

Effects of live animal performance and hemoglobin level on special-fed veal carcass characteristics. Meat Sci. 41 (1995), 89-96

ZMP (Zentrale Markt- und Preisberichtstelle GmbH):

ZMP Bilanz Vieh und Fleisch 1998 auf CD-ROM, ISSN 1436-0357 (1999)

Received: 30.08 .1999

Accepted: 04.10.1999

Authors' addresses

Dr. MARTIN R. L. SCHEEDER, Prof. Dr. MICHAEL KREUZER

Institute of Animal Science, Animal Nutrition

ETH Zurich, ETH-Zentrum

CH-8092 Zurich

Switzerland

Dipl.-Ing. agr. BERND BECKER

Research Centre for Animal Production and Technology,

University of Göttingen, P.O. Box 15 53,

D-49364 Vechta

Germany 
Arch. Tierz., Dummerstorf 42 (1999) 6, 554

\title{
Buchbesprechung
}

\author{
Lehrbuch der Anatomie der Haustiere, Band II - Eingeweide
}

RICHARD NICKEL, AUGUST SCHUMMER und EUGEN SEIFERLE

Herausgeber: JOSEF FREWEIN, HAGEN GASSE, RUDOLF LEISER, HEIDE ROOS, HARALD THOME, BERND VOLLMERHAUS, HELMUT WAIBL

8. vollständig neubearbeitete Auflage, 482 Seiten, 573 Abbildungen, davon 92 mehrfarbig, 17 Tabellen und Übersichten, Parey Buchverlag Berlin, 1999, ISBN 3-8263-3179-6, 228,00 DM, 1664,00 öS, 210,00 sFr

Vom Parey Buchverlag erschien in zahlreichen Auflagen und Bänden seit Jahrzehnten in deutscher oder cnglischer Sprache das bewährte Standardwerk zur Anatomie der Haustiere. Nunmehr liegt die 8. vollständig neubearbeitete Auflage des deutschsprachigen Bandes II „Eingeweide“ vor. Wie bereits in der kürzlich erschienenen Neuauflage des III. Bandes, zeigt auch dieser II. Band eine konsequente Weiterentwicklung der didaktischen Verbesserungen und des Layouts. Mit einer erweiterten kompetenten Autorengruppe aus Deutschland und der Schweiz erfolgte auf der Grundlage đes bewährten Konzeptes, abgefaßt in einer prägnanten Diktion, eine völlige Neufassung der meisten Abschnitte. Eine größere Anzahl von Abbildungen wurde in dieser Neufassung ausgetauscht oder bearbeitet. Der Neubearbeitung wurde die aktuelle Nomina Anatomica Veterinaria zugrunde gelegt.

Hauptanliegen dieses Bandes ist die vollständige Darstellung der makroskopisch-anatomischen Strukturen der Eingeweide der Haussäugetiere Hund, Katze, Schwein, Hauswiederkäuer und Pferd unter Berücksichtigung der Funktionen. Jedes Kapitel wird eingeleitet von einer vergleichenden anatomischen Betrachtung, gefolgt von der Beschreibung der morphologischen und funktionellen Gegebenheiten der Organsysteme mit der Darstellung der für jede Tierart artspezifischen Merkmale der Organe. Die acht, jeweils durch grau hinterlegte Kurzzusammenfassungen, eingeleiteten Hauptabschnitte beinhalten die Organsysteme bzw. Organe Eingeweide und Körperhöhlen, Mundhöhle und Schlundkopf, Speiseröhre, Magen, Darm, Darmanhangsdrüsen, Milz, Atmungsapparat, Hamorgane sowie männliche und weibliche Geschlechtsorgane. Ein umfangreiches Literatur- und Sachwortverzeichnis beschließt dieses didaktisch hervorragend aufbereitete Buch. In diesem Lehrbuch, vom Verlag in gewohnt hervorragender Weise ausgestattet, sei auf die sehr große Anzahl nach topographischen Gesichtspunkten sorgfältig ausgewählten Abbildungen, deren umfangreicher Kommentierung, der klaren Textfassung sowie die eine gute Übersicht gewährleistenden drucktechnischen Besonderheiten, hingewiesen.

Dieses Standaráwerk ist für Lehre, Forschung und Praxis hervorragend geeignet und bedarf eigentlich, weil unverzichtbar, keiner besonderen Empfehlung. 